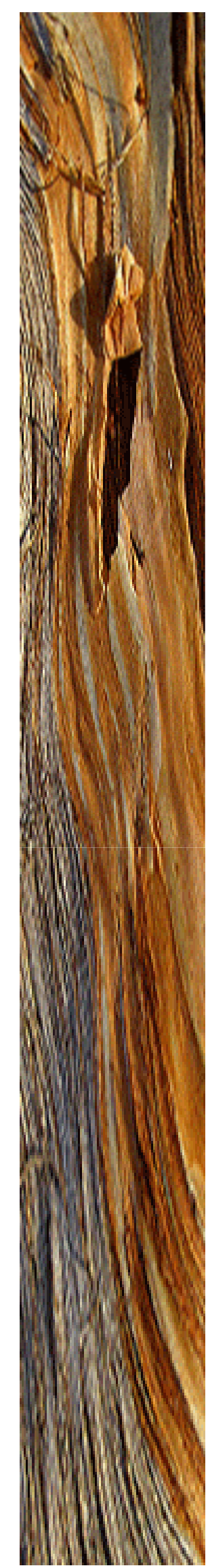

International Journal of Critical Indigenous Studies

\author{
Volume 2, Number 1, 2009
}

\title{
Book Review: Everything You Know About Indians is Wrong
}

Paul Chaat Smith. University of Minnesota Press, 2009

\section{Reviewed by Maggie Walter}

This book achieves a balancing act that will be the envy of Indigenous authors, myself among them. Its articulate demonstration of the utter absurdities, past and present, of the culturally embedded representations of Native Americans charms rather than alienates its (non-Indigenous) audience. This is not to say that Chaat Smith's essays will not challenge or confront its readers; they will. Rather, his expose uses razor sharp observations, clarity of language, self-deprecating authorial tone and clever juxtapositions of humour and tragedy to blunt the power to take umbrage as a dismissive response. The book makes its searing critique engaging and irrefutable.

Drawn from a series of essays published by Chaat Smith over the past decade the volume is empirically, rather than a theoretically focussed. The essays are thematically unified by the role of the camera and images in how representations have constructed 'the Native American' over the last two centuries. In doing so, the topic extends past the pictorial to a much wider spotlight on the centrality of such images to the social, political and cultural positioning of Native Americans, historically and contemporaneously. It is in the books development from a series of essays that my only real criticism emerges. This genesis becomes obvious as the reader progresses through the volume. While the concept of images underlies all the essays, the connective relevance of these is harder to discern in some essays than others and towards the end, a slight repetition reduces the impact of the argument. That aside, the essays provide a powerful narrative which reflect the author's cultural studies alignment and curator position at the National Museum of the American Indian at the Smithsonian Institute. Chaat Smith uses a personal tale of his Native American grandfather's use of photos to garner donations to his Comanche Reformed Church as introduction. The next few essays address the on-going non-Indigenous demand for a clichéd performance of the romanticised Indian of their own construction. Chaat Smith makes the telling point that the desire for this version is so embedded that articles, literature, cultural items, rituals and even people manufactured by non-Indians are accepted over the genuine article if they reflect this image. Racism as romanticism confines Indian agency in an ideological prison (p. 91). Such racism is operationalised by the dominant discourse of authenticity as the unflattering comparative touchstone against which the complex reality of Native American lives, art, or depictions of contemporary Native American activists are judged.

The impact of images on Native American realities is to the foreground in the essays relating to representations in the movies. Chaat Smith conducts a pithy exploration of the long-term, fraught but fascinated relationship of Native Americans with Hollywood and Hollywood with Native Americans. In the movies, the twin narratives of the romanticised, noble, wise and spiritual Indian and the vilified, drunken, sad and broken Native American co-exist: a combination almost impermeable to alternative visions. The pervading, but personally remote, power of these images, argues Chaat Smith, allow non-Indigenous America to disregard and ignore contemporary Native America and in the process conveniently forget that it's own contemporary reality is built on a continuing legacy of violent dispossession of land, sovereignty and, in some cases, existence of the nation's Indigenous owners. As Chaat Smith notes, in this self induced amnesia '... the act of remembering turns you into a heretic, a revolutionary, a troublemaker'. Remembering is also confounded by the faux narrative of authenticity so that 'to assert the relevance of an Indian past and present makes one hostage to identity politics, multiculturalism and other narrow and suspect agenda' (p. 91). 
As an Indigenous Australian I cannot help but wonder how a similar book would be received in the Australian context. There are certainly similarities in the imaged and imagined representations that overshadow our realities. Similarly romanticized as the noble savage and/or vilified as the brutal savage, for Australian Aborigines, it has been, an continues to be, rather more of the latter and less of the former. These two depiction, however, are two sides of the same racialised coin. As Chaat Smith makes clear, either approach dehumanises and objectifies its subjects via their racialised demeaning discourses, disallowing full societal participation in the process. And it is the dual complexity and ordinariness of flawed humanness of the Native Americans Chaat Smith engages with, those personally known in contemporary times and those historical figures whose objectification is almost complete, that is the central message of this book. In doing so, he makes this humanity a political statement. 